\title{
Influence of Induced Soil Compaction on the Growth, the Yield and the Soil Loss Resulting from the Groundnut Harvesting
}

\author{
${ }^{1}$ Ewetola Esther Abosede, ${ }^{1}$ Ibrahim Memunat A and ${ }^{2}$ Isola John Oluwasina \\ ${ }^{I}$ Department of Crop production and Soil Science, Ladoke Akintola University of Technology, Ogbomoso, \\ Oyo state Nigeria, 210001, +2348022386143 \\ ${ }^{2}$ Department of Soil Science, Forest Research Institute, Ibadan, Nigeria,e-mail: ewetola68@gmail.com
}

Received May 29, 2020; Revised September 14, 2020; Accepted 18 September 2020

\begin{abstract}
The research was conducted to study the growth and the yield of the groundnut plant and to quantify the soil loss after groundnut harvesting as influenced by induced soil compaction. A ten kilogram of soil was packed in the pots with an initial bulk density of $1.05 \mathrm{Mg} \mathrm{m}^{-3}$, then it were compressed to $1.57,1.72,1.88,2.04$, and $2.42 \mathrm{Mg} \mathrm{m}^{-3}$. The research was conducted in a completely randomized design with three replications. Groundnut seeds were sown in pots and the plant growth data were collected in a 2-week interval while force and energy of harvesting and soil loss due to groundnut harvesting were determined at 12 weeks after sowing. Data were analyzed using ANOVA and Fishers LSD at $\mathrm{P}=0.05$. Soil compacted to $1.88 \mathrm{Mgm}^{-3}$ produced more taller plant, more higher number of leaves and branches than control. Soil compaction significantly reduced the number of pods, roots, and fresh root weight compared to control. Bulk density $\left(2.04 \mathrm{Mgm}^{-3}\right)$ required a significantly higher force $(42.47 \mathrm{~N})$ and energy $(45.73 \mathrm{~J})$ in harvesting than control and other compaction levels. Soil loss due to the groundnut harvesting increased (13$42 \%$ ) in all compaction levels although statistically not different. Soil compaction beyond $1.88 \mathrm{Mg} \mathrm{m}^{-3}$ could affect the growth and the yield of groundnut and could increase the soil loss at harvesting.
\end{abstract}

Keywords: Bulk density, groundnut, soil compaction, soil loss

\begin{abstract}
ABSTRAK
Penelitian ini dilakukan untuk mempelajari pertumbuhan dan hasil tanaman kacang tanah serta menghitung kehilangan tanah setelah panen kacang tanah yang dipengaruhi oleh pemadatan tanah yang diinduksi. Sepuluh kilogram tanah dikemas dalam pot dengan berat isi awal $1,05 \mathrm{Mg} \mathrm{m}$-3, kemudian dipadatkan menjadi $1,57,1,72,1,88,2,04$, dan $2,42 \mathrm{Mg}$ m-3. Penelitian dilakukan dalam Rancangan Acak Lengkap dengan tiga ulangan. Benih kacang tanah disemai dalam pot dan data pertumbuhan tanaman dikumpulkan dalam selang waktu 2 minggu, sedangkan tenaga dan energi panen dan kehilangan tanah akibat panen kacang tanah ditentukan pada 12 minggu setelah tanam. Data dianalisis menggunakan ANOVA dan Fishers LSD pada $\mathrm{P}=0,05$. Tanah yang dipadatkan menjadi 1,88 Mgm-3 menghasilkan tanaman yang lebih tinggi, jumlah daun dan cabang yang lebih banyak dari pada kontrol. Pemadatan tanah secara signifikan menurunkan jumlah polong, akar, dan bobot akar segar dibandingkan dengan kontrol. Kepadatan curah (2,04 Mgm-3) membutuhkan gaya yang jauh lebih tinggi $(42,47 \mathrm{~N})$ dan energi $(45,73 \mathrm{~J})$ dalam pemanenan dibandingkan kontrol dan tingkat pemadatan lainnya. Kehilangan tanah akibat panen kacang tanah meningkat (13-42\%) di semua tingkat pemadatan meskipun secara statistik tidak berbeda. Pemadatan tanah melebihi $1,88 \mathrm{Mg} \mathrm{m}-3$ dapat mempengaruhi pertumbuhan dan hasil kacang tanah dan dapat meningkatkan kehilangan tanah pada saat panen.
\end{abstract}

Kata Kunci: Kepadatan curah, kacang tanah, pemadatan tanah, kehilangan tanah

\section{INTRODUCTION}

Soil compaction is the process of increasing the density of soil by packing the particles closer together, causing a reduction in the volume of air

\footnotetext{
J Trop Soils, Vol. 25, No. 3, 2020: 147-156

ISSN 0852-257X; E-ISSN 2086-6682
}

(Wilson and Lorang 2000; Keller et al. 2013). Soil compaction could be a serious problem in agriculture because it will have negative effects on the soil properties and the crops grown in the soil. Cavatassi et al. (2011) stated that soil compaction directlyaffects traffic-ability, soilworkability, and harvestability of root crops. According to Abdulai and Huffman (2005), many soil properties are 
negatively affected by compaction as it reduces soil pore and may increase its shearing strength (Keller et al. 2013)

The most common causes of agriculture compaction are trampling by livestock, pressure imposed by tractor tires, tillage implementation, raindrop impact, minimal crop rotation, and plant with large root or tuber (Etana et al. 2013). Out of all the causes of soil compaction, the one caused by agricultural machinery which was grouped into tillage induced and traffic included compaction is most fatal (Rigo 2002). Compaction caused by these machinenery s, especially the ones below the plow layer is more concern since it is not easily selfcorrecting, therefore it will be difficult to reverse or correcting (Nunes et al. 2015).

In Nigeria, problems of soil compaction are increasing as more farmers are adopting the use of tractors on their field without considering the possible negative effects on the soil. Thus, the country has lost a vast area of arable land through increased use of tillage implementation and improper agriculture practices (FAO 2011). Soil compaction in cultivated lands affect mostly the upper layer of soil (topsoil compaction) but the effect could also be on the subsoil layer. Generally, compaction at the topsoil layer has negative effects on the soil except in a few cases where a slight degree of topsoil compaction can be beneficial for some type of soils especially sandy soils (Bohringer and Loschel 2006). The negative impacts of soil compaction are significant because it has detrimental effects on soils such as increasing bulk density, reducing porosity, water, and nutrient uptake by the plants, and crop yields (Chen et al. 2014). Obafemi and Mouiz (2019) also observed a significantly decrease in the height and the leaf area of maize plants with a higher level of soil compaction. About a $38 \%$ reduction in the grain yield of wheat was reported from soil which is compacted to a bulk density of $1.93 \mathrm{Mgm}^{-3}$ at $0.15 \mathrm{~m}$ depth (Isabirye et al. 2006). Similarly, soil compaction was reported to have negative effects on the establishment, the growth, and the yield of plants (Salem 2015). Aiyelari et al. (2013) also reported that soil compaction reduced growth and pod yield of groundnut by restricting root development as well as water and air movement in the soil.

Soil erosion occurring through the process of compaction is one of the major processes leading to increase runoff and soil erosion (Rickson 2014). Water and wind erosion, mass movements, and more recently, tillage erosion are considered the most important soil erosion processes and are therefore the most commonly studied causes of soil loss.
However, attention has been drawn recently to an often neglected, but significant, a soil erosion process called soil loss due to crop harvesting (Poesen et al. 2001; Poesen 2018). This type of soil loss caused by the harvesting of root, tuber, and bulb crops such as carrot (Daucus carota L.), cassava (Manihot spp.), sweet potato (Ipomoea batatas (L.) Lam), yam (Dioscorea spp.), onion (Allium cepa L.), cocoyam (Colocasia esculenta), are often overlooked (Isabirye et al. 2006; Ruysschaert et al. 2006; Oshunsanya 2016). Fine earth adhering to the crop, loose soil, and rock fragments are harvested and removed from the field together with the crop. Consequently, soil sticking to the harvested crops are exported and rarely returned to the field. However, soil loss due to crop harvesting in a farmer's field is now gaining attention all over the world.

Nowadays in Nigeria, research efforts in curbing water erosion increase (Babalola et al. 2007; Babalola 2007; Oshunsanya et al. 2010; Oku et al. 2016; Ewetola 2017) among several others. Most of these efforts focused on water and tillage soil erosion, whereas the significant amounts of soil that is lost from arable land during harvesting of root, tuber, and bulb crops are receiving low attention (Oshunsanya 2016; Dada et al. 2016 Oshunsanya et al. 2018).

To meet the need of food for the growing population in Nigeria, the use of mechanized agriculture that results in soil compaction is inevitable. The compaction of soil has the potential to reduce the productive capacity of farmlands as well can aggravate soil loss due to crop harvesting which is rapidly becoming a significant type of soil erosion. Groundnut (Arachis hypogea L.) is an economic crop that is grown on a large scale. The soils that adhere to the plant during harvesting may not be taken out of the field. However, the harvested plants could be packed away from the plots. At this point, some quantity of soil can be lost from the field.

Therefore, this study is an attempt to investigate soil loss due to groundnut harvesting as influenced by induced soil compaction with the objectives (i) to determine the effect of soil compaction on the growth and yield of groundnut and (ii) to quantify soil loss due to groundnut harvesting.

\section{MATERIALS AND METHODS}

The experiment was carried out at the Teaching and Research Farm, Ladoke Akintola University of Technology, Ogbomoso. The experiment was established between April and June 2019. Ogbomoso lies on the latitude $8^{\circ} 10^{\prime} 18^{\prime \prime} \mathrm{N}$ and longitude 
Table 1. Soil Samples at different level of compaction used in the experiment.

\begin{tabular}{ccccc}
\hline Treatment & $\begin{array}{c}\text { Initial Soil Height } \\
\text { before compaction } \\
(\mathrm{cm})\end{array}$ & $\begin{array}{c}\text { Final Soil Height } \\
\text { after compaction } \\
(\mathrm{cm})\end{array}$ & $\begin{array}{c}\text { Volume } \\
\left(\mathrm{cm}^{3}\right)\end{array}$ & $\begin{array}{c}\text { Bulk Density } \\
\left(\mathrm{Mgm}^{-3}\right)\end{array}$ \\
\hline T0 & 20 & 20 & 10619.96 & 1.05 \\
T1 & 20 & 14 & 7433.972 & 1.57 \\
T2 & 20 & 12.6 & 6690.575 & 1.72 \\
T3 & 20 & 11.6 & 6159.577 & 1.88 \\
T4 & 20 & 11 & 5840.978 & 2.04 \\
T5 & 20 & 9.5 & 5044.481 & 2.42 \\
\hline
\end{tabular}

$4^{\circ} 16^{\prime} 15^{\prime \prime} \mathrm{E}$ in the Southern guinea savannah agroecological zone of Nigeria. It is characterized by a bimodal rainfall distribution pattern. The early rainy season commences in late March and ends in late July or early August followed by a short dry spell in August. The late rainy season commences from September to November. It has a mean total annual rainfall of $1217 \mathrm{~mm}$ and an average annual temperature of $26^{\circ} \mathrm{C}$.

\section{Soil sampling and analysis}

Soil samples from the Teaching and Research Farm were collected from $0-15 \mathrm{~cm}$ depth with the use of a soil auger. The soil was air-dried, ground, and sieved through a $2 \mathrm{~mm}$ mesh size.

The routine analysis of the soil for the experiment was carried out at IITA (International Institute for Tropical Agriculture) Ibadan. Particle size analysis was done by the hydrometer method (Gee and Or 2002). Soil pH was determined with the $\mathrm{pH}$ meter using a glass electrode in a soil: water ratio of 1:1. Organic carbon was determined by the Walkley-Black procedure described by (Nelson and Sommers 1986). Exchangeable cations were extracted with $1 \mathrm{~N}$ ammonium acetate. Exchangeable acidity was extracted with $1 \mathrm{~N} \mathrm{KCl}$ and titrated against $0.01 \mathrm{NaOH}$. Available phosphorus was determined using the Bray II method (Bray and Kurtz 1945) while Total nitrogen was determined by the Macro-Kjeldahl method (Bremner 1965).

\section{Experimental design and crop establishment}

The study is a modified method of Aiyelari et al. (2013). The study used a completely randomized design with 5 compaction levels with three replications. Soil sample of $10 \mathrm{~kg}$ weight was packed into a 10-liter plastic pot. The soil sample has a bulk density of $1.05 \mathrm{Mg} \mathrm{m}^{-3}$ with the initial height of 20 $\mathrm{cm}$ (control). Three seeds of groundnut were sown in each pot before the soils were compacted by placing the loads of $4.5 \mathrm{~kg}$ on the soils. The soil was moistened with water before compressing to heights of $14,12.6,11.6,11.0$, and $9.5 \mathrm{~cm}$ which was respectively equivalent to $1.57,1.72,1.88,2.04$, and $2.42 \mathrm{Mg} \mathrm{m}^{-3}$ (Table 1). Data on the following parameters: plant height, number of leaves, stem girth, number of branches, number of pods, fresh pod weight, fresh seed weight, number of roots, fresh root weight, and total fresh biomass were recorded at 2-week interval after sowing for 12 weeks.

Force of harvesting was determined with the aid of string balance to pull out the groundnut. The hook of the balance was fitted to the base of the plant and was pulled out of the soil. The highest reading on the balance was recorded. Force of harvesting was obtained from equation (1) as follow. Force $(\mathrm{N})=$ Weight $(\mathrm{g}) \times$ Acceleration due to gravity $\left(\mathrm{gcm}^{-1} \mathrm{sec}^{-1}\right)$......

Energy $(\mathrm{J})$ used in harvesting was calculated as in equation (2):

Energy $(\mathrm{J})=$ Force $(\mathrm{N}) \mathrm{x}$ distance $(\mathrm{cm})$

Soil loss due to the groundnut harvesting was recorded as the quantity of soil adhering to the pulled roots which were carefully separated from the roots and weighed with a sensitive scale.

\section{Statistical Analysis}

Data recorded were subjected to Analysis of Variance (ANOVA) and significant means were compared using the Least Significant Difference (LSD) at $5 \%$ probability level (SAS 2002). Regression analysis was done to obtain a relationship between soil bulk density and other parameters such as force of harvesting, energy of harvesting, and soil loss.

\section{RESULTS AND DISCUSSION}

\section{Physical and chemical properties of the soil used for the study}

The initial physical and chemical properties of the soil used in the experiment are presented in Table 2. The soil reaction was slightly alkaline, with low 
Table 2. Characteristics of the soil used in the experiment.

\begin{tabular}{llll}
\hline Parameters & Unit & Value & Level* \\
\hline $\mathrm{pH} \mathrm{H} \mathrm{H}_{2} \mathrm{O}(1: 1)$ & & 7.4 & Slightly neutral \\
Organic carbon & $\mathrm{g} \mathrm{kg}^{-1}$ & 7.8 & Low \\
Total N & $\mathrm{g} \mathrm{kg}^{-1}$ & 6.7 & Medium \\
Available P (Melich 3) & $\mathrm{mg} \mathrm{kg}^{-1}$ & 19.49 & Medium \\
Exchangeable K & $\mathrm{cmol}(+) \mathrm{kg}^{-1}$ & 0.11 & Low \\
$\mathrm{Na}$ & $\mathrm{cmol}(+) \mathrm{kg}^{-1}$ & 0.03 & Low \\
$\mathrm{Ca}$ & $\mathrm{cmol}(+) \mathrm{kg}^{-1}$ & 4.43 & Medium \\
$\mathrm{Mg}$ & $\mathrm{cmol}(+) \mathrm{kg}^{-1}$ & 0.23 & Low \\
$\mathrm{CEC}$ & $\mathrm{cmol}(+) \mathrm{kg}^{-1}$ & 4.83 & Low \\
Sand & $\mathrm{g} \mathrm{kg}^{-1}$ & 800.00 & \\
Silt & $\mathrm{g} \mathrm{kg}^{-1}$ & 80.00 & \\
Clay & $\mathrm{g} \mathrm{kg}^{-1}$ & 120.00 & \\
Textural class & $\mathrm{Loamy} \mathrm{sand}$ & & \\
\hline
\end{tabular}

Note: * Based on Esu (1991) and Chude et al. (2011); CEC = Cation exchangeable capacity

concentrations of $\mathrm{P}, \mathrm{N}, \mathrm{K}$, and $\mathrm{Ca}$ and a sandy loam texture.

\section{Groundnut growth}

The compaction of soil from $1.05 \mathrm{Mgm}^{-3}$ to 2.42 $\mathrm{Mgm}^{-3}$ soil bulk densities significantly affected plant heights at 4 and 6 weeks after sowing (WAS) (Table 3). Soil bulk density of $1.88 \mathrm{Mgm}^{-3}$ recorded the higher plant height of 12.7 and $17.7 \mathrm{~cm}$ respectively, at 4 and 6 WAS (Figure 1). The results indicated that compaction of soil beyond $1.88 \mathrm{Mgm}^{-3}$ soil bulk density would affect groundnut height as a result of the reduction in pore spaces for water and air which are available for the plant roots. This result supported by Chen et al. (2014) that soil compaction restricts plant growth by increasing the mechanical resistance of the soil. Similarly, Aiyelari et al. (2013) reported that the plant height of the groundnut was reduced with an increase the levels of compaction.

Soil compaction significantly influenced the groundnut number of leaves (NOL) at 6,8 , and 10 WAS. At 6 WAS, soil bulk density of 1.88 and 2.04
$\mathrm{Mgm}^{-3}$ recorded the higher NOL. However, at 8 and 10 WAS, higher NOL were obtained from soil bulk density of $1.88 \mathrm{Mgm}^{-3}$ than other compaction levels (Figure 2). The reduction in groundnut NOL could be attributed to the deprivation of plants from air and water and nutrient as a result of compression of the pore spaces within the soil (Obafemi and Mouiz 2019). Aiyelari et al. (2013) reported that the number of leaves from the groundnut was not affected by soil compaction because compaction could limit crop growth root access to reserves of soil moisture and nutrients deeper down the soil layer.

The number of groundnut branches were not influenced by soil compaction from 2 to 10 WAS except at 12 WAS which had a higher value (25.0) under soil bulk density of $1.88 \mathrm{Mgm}^{-3}$ than other imposed treatments (Figure 3). This revealed that compaction beyond this bulk density could impair the growth and development of groundnut plants. Soil compaction resulting in mechanical impedance has been reported to impede plant development and growth of various crops (Keller et al. 2013).

Table 3. Yield and biomass parameters of groundnut plants as influenced by soil compaction.

\begin{tabular}{ccccc}
\hline Treatment & $\begin{array}{c}\text { Initial Soil Height } \\
\text { before compaction } \\
(\mathrm{cm})\end{array}$ & $\begin{array}{c}\text { Final Soil Height } \\
\text { after compaction } \\
(\mathrm{cm})\end{array}$ & $\begin{array}{c}\text { Volume } \\
\left(\mathrm{cm}^{3}\right)\end{array}$ & $\begin{array}{c}\text { Bulk Density } \\
\left(\mathrm{Mgm}^{-3}\right)\end{array}$ \\
\hline T0 & 20 & 20 & 10619.96 & 1.05 \\
T1 & 20 & 14 & 7433.972 & 1.57 \\
T2 & 20 & 12.6 & 6690.575 & 1.72 \\
T3 & 20 & 11.6 & 6159.577 & 1.88 \\
T4 & 20 & 11 & 5840.978 & 2.04 \\
T5 & 20 & 9.5 & 5044.481 & 2.42 \\
\hline
\end{tabular}




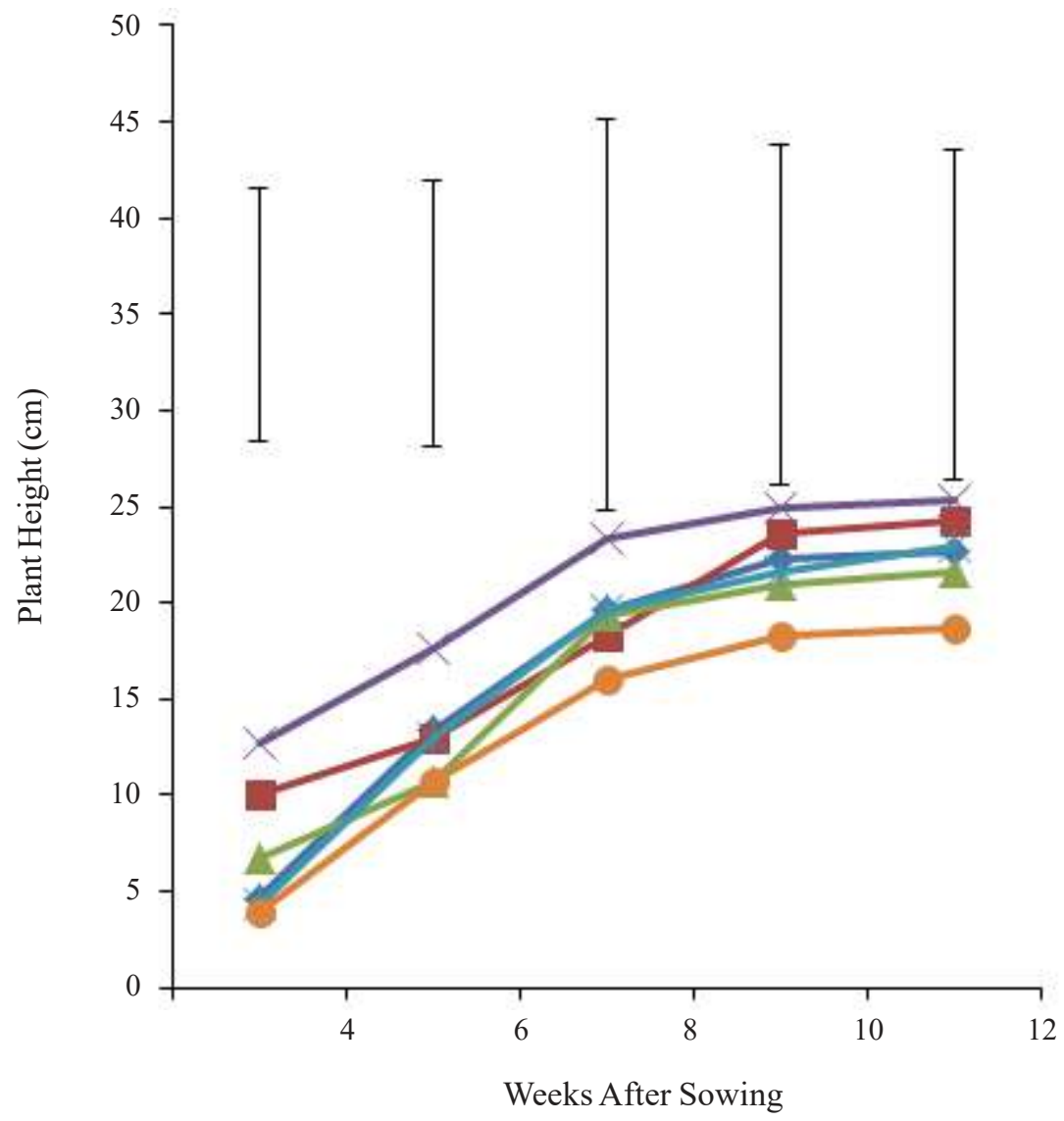

Figure 1: Influence of soil compaction on plant height of groundnut. $-\bullet: 1.05\left(\mathrm{Mg} \mathrm{m}^{-3}\right),-1.57(\mathrm{Mg}$ $\left.\mathrm{m}^{-3}\right), \longleftarrow: 1.72\left(\mathrm{Mg} \mathrm{m}^{-3}\right), \longleftarrow: 1.82\left(\mathrm{Mg} \mathrm{m}^{-3}\right)$, $2.04\left(\mathrm{Mg} \mathrm{m}^{-3}\right)$ $=2.42\left(\mathrm{Mg} \mathrm{m}^{-3}\right)$

The soil compaction did not affect the stem girth of groundnut plants through all period of the experiment from 2 to 10 WAS (Table 4) (Figure
4). However at $12 \mathrm{WAS}$, groundnut plants with soil bulk density of $2.04 \mathrm{Mg} \mathrm{m}^{-3}$ recorded significantly thicker stems $(15.92 \mathrm{~mm})$ whereas

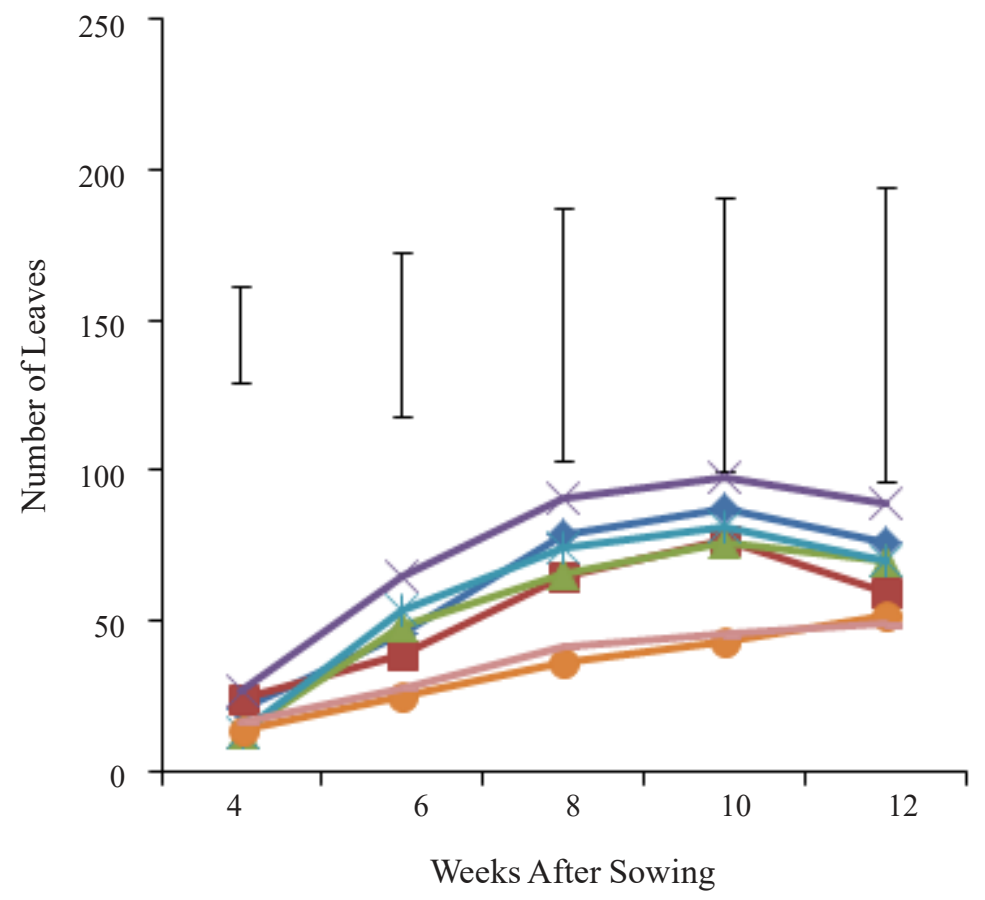

Figure 2. Influence of soil compaction on the number of leaves of groundnut. $-\longrightarrow: 1.05\left(\mathrm{Mg} \mathrm{m}^{-3}\right),-1.57$ $\left(\mathrm{Mg} \mathrm{m}^{-3}\right), \longleftarrow: 1.72\left(\mathrm{Mg} \mathrm{m}^{-3}\right), \longleftarrow: 1.82\left(\mathrm{Mg} \mathrm{m}^{-3}\right)$, $: 2.04\left(\mathrm{Mg} \mathrm{m}^{-3}\right),-2: 2.42\left(\mathrm{Mg} \mathrm{m}^{-3}\right)$. 


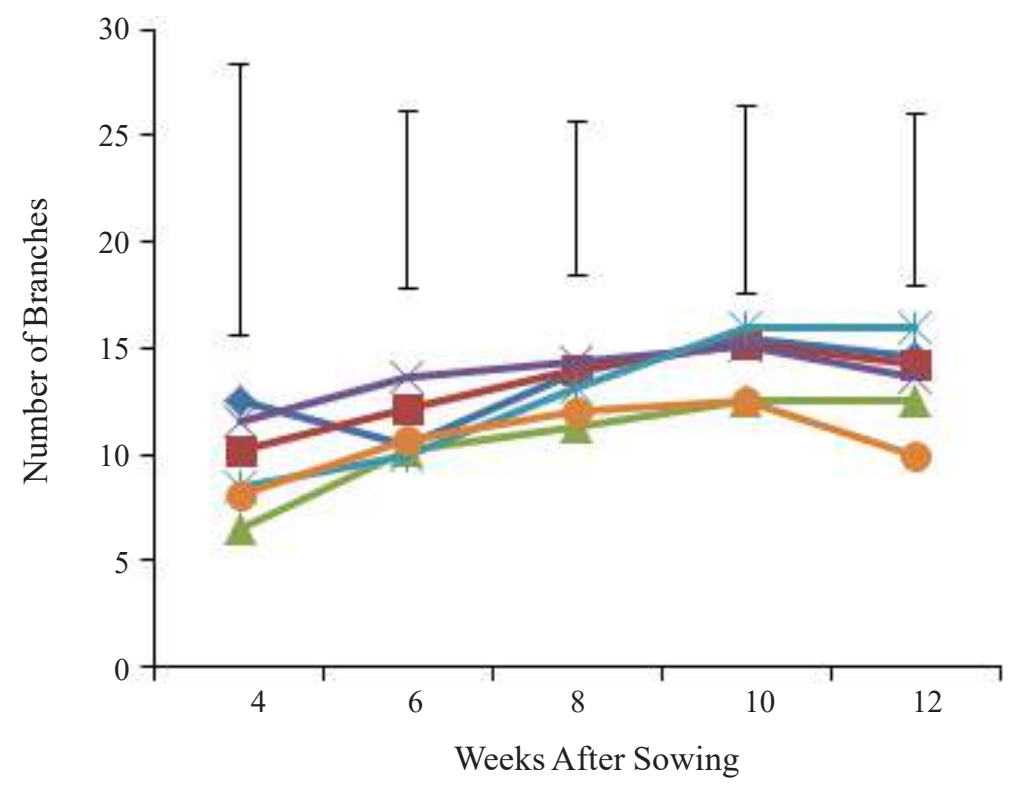

Figure 3. Influence of soil compaction on the stem girth of groundnut. $-1.05\left(\mathrm{Mg} \mathrm{m}^{-3}\right),-1.57(\mathrm{Mg}$ $\left.\mathrm{m}^{-3}\right),-1.72\left(\mathrm{Mg} \mathrm{m}^{-3}\right), \longleftarrow: 1.82\left(\mathrm{Mg} \mathrm{m}^{-3}\right)$, $: 2.04\left(\mathrm{Mg} \mathrm{m}^{-3}\right),-2.42\left(\mathrm{Mg} \mathrm{m}^{-3}\right)$.

plants grown in pots with soil $2.42 \mathrm{Mgm}^{-3}$ had the thinner stems $(9.95 \mathrm{~mm})$.

\section{Yield and its components}

Soil compaction had a significant effect on the number of pods (Table 4). There was a decreasing the number of pods with an increasing soil compaction levels relative to the control $(1.05 \mathrm{Mg}$ $\left.\mathrm{m}^{-3}\right)$. Similarly, increased soil compaction significantly reduced the number of roots when compared with non- compacted soil (control). However, soil compacted to $2.04 \mathrm{Mg} \mathrm{m}^{-3}$ was statistically similar to the control. Furthermore, the fresh root weights of groundnut were decreased with an increase in soil compaction levels compared to the control. Fresh pod weight, fresh seed weight, total fresh biomass, and depth of root penetrations showed no significant difference among soil compaction levels. However, the compacted soils recorded lower fresh pod, fresh root weights, and depth of root penetration than control, whereas total fresh biomass did not have a consistent trend. The reduction in pod yield and other yield components of groundnut with the increased of soil compaction is in agreement with Obafemi and Mouiz (2019) that in a greenhouse study, maize yield decreased with a higher level of soil compaction.

Compaction usually alters the pore size distribution of the soil by reducing the large pores that are responsible for proper aeration and moisture content. This result revealed that compacting the soil beyond $1.88 \mathrm{Mgm}^{-3}$ reduced total fresh biomass which a reflection of poor growth and development. The general reduction in yield and yield components of groundnut with the increased of compaction levels could be attributed to the restricted root growth and proliferation that could have resulted in a reduced ability of the plant to uptake $o$ water and nutrient from the soil. The result is in line with Juorholami et al. (2018) who reported that the negative impact of soil compaction on root growth was due to limited availability of water and nutrients for satisfactory growth and yield.

Table 4. Force and energy of harvesting of groundnut plants as influenced by soil compaction.

\begin{tabular}{ccc}
\hline $\begin{array}{c}\text { Bulk Density } \\
\left(\mathrm{Mg} \mathrm{m}^{-3}\right)\end{array}$ & $\begin{array}{c}\text { Force of harvesting } \\
(\mathrm{N})\end{array}$ & $\begin{array}{c}\text { Energy used in harvesting } \\
(\mathrm{J})\end{array}$ \\
\hline 1.05 & 19.60 & 13.07 \\
1.57 & 32.67 & $28.75 \mathrm{ab}$ \\
1.72 & 39.20 & $39.20 \mathrm{a}$ \\
1.88 & 31.03 & $35.28 \mathrm{a}$ \\
2.04 & 42.47 & $45.73 \mathrm{a}$ \\
2.42 & 35.93 & $35.28 \mathrm{a}$ \\
LSD $_{(0.05)}$ & 18.34 & 13.03 \\
\hline
\end{tabular}

LSD- Least significant difference 


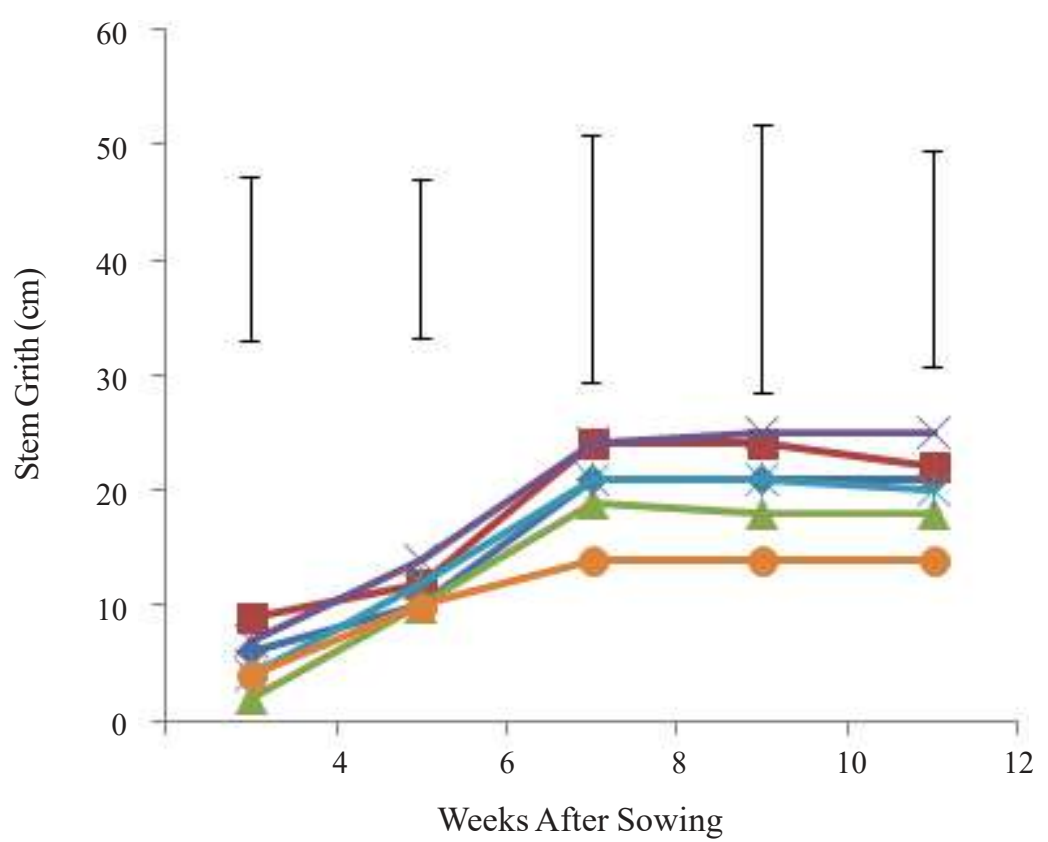

Figure 4. Influence of the soil compaction on the number of branches of groundnut. $-\bullet: 1.05\left(\mathrm{Mg} \mathrm{m}^{-3}\right)$, $\neg: 1.57\left(\mathrm{Mg} \mathrm{m}^{-3}\right), \multimap: 1.72\left(\mathrm{Mg} \mathrm{m}^{-3}\right), \smile: 1.82\left(\mathrm{Mg} \mathrm{m}^{-3}\right), \longleftarrow: 2.04\left(\mathrm{Mg} \mathrm{m}^{-3}\right), \smile$ : $2.42\left(\mathrm{Mg} \mathrm{m}^{-3}\right)$.

Force and Energy of harvesting under soil compaction

The force of harvesting groundnut was significantly affected by soil compaction (Table 4 ). Soil compacted to 1.72 and $2.04 \mathrm{Mg} \mathrm{m}^{-3}$ bulk density significantly required higher force for harvesting compared to control $\left(1.05 \mathrm{Mg} \mathrm{m}^{-3}\right)$ while other compaction treatments were not different from control. Energy used in the harvesting groundnut was significantly influenced by soil compaction levels. All compaction levels except $1.57 \mathrm{Mg} \mathrm{m}^{-3}$ soil bulk density significantly increased energy expended in harvesting groundnut relative to the control. This result revealed that more force and energy in harvesting increased with compaction levels could be related to the increase in bulk density which could have made the soil hard and thereby required more force and energy for uprooting the plant. It is consistent with the report by Aiyelari et al. (2013) whos stated the force and energy of harvesting increased with increasing bulk density.

\section{Soil loss due to groundnut harvesting under different compaction levels}

Soil compaction had no significant effect on soil loss due to groundnut harvesting. However, soil with a bulk density of $1.57 \mathrm{Mg} \mathrm{m}^{-3}$ recorded the highest soil loss $(82.03 \mathrm{~g})$ while the least (57.77 g) was from soil bulk density of $1.57 \mathrm{Mg} \mathrm{m}^{-3}$ (Table 5). The result revealed that soil compaction can increase soil loss due to crop harvesting. The use of heavy machinery can induce compaction on the field which could have a consequential effect on the amount of soil that can adhere to the root of groundnut during harvesting. The nonsignificance of soil loss due to groundnut harvesting was similar to the findings of Dada et al. (2016) who reported no significant difference in soil loss due to yam harvesting from two locations (FUNAAB and Alabata) in Nigeria. This result also corroborated Lindemans (2002) who identified a reduction in soil loss through compaction but stated that this relationship has an elastic limit.

Table 5. Soil loss due to groundnut harvesting as influenced by soil compaction.

\begin{tabular}{cc}
$\begin{array}{c}\text { Bulk Density } \\
\left(\mathrm{Mg} \mathrm{m}^{-3}\right)\end{array}$ & $\begin{array}{c}\text { Soil Loss } \\
\left(\mathrm{g} \mathrm{plant}^{-1}\right)\end{array}$ \\
\hline 1.05 & 57.77 \\
1.57 & 65.53 \\
1.72 & 74.57 \\
1.88 & 78.45 \\
2.04 & 75.33 \\
2.42 & 82.03 \\
LSD $_{(0.05)}$ & $15.36^{\mathrm{ns}}$ \\
\hline
\end{tabular}

LSD- least significant difference; ns- not significant 


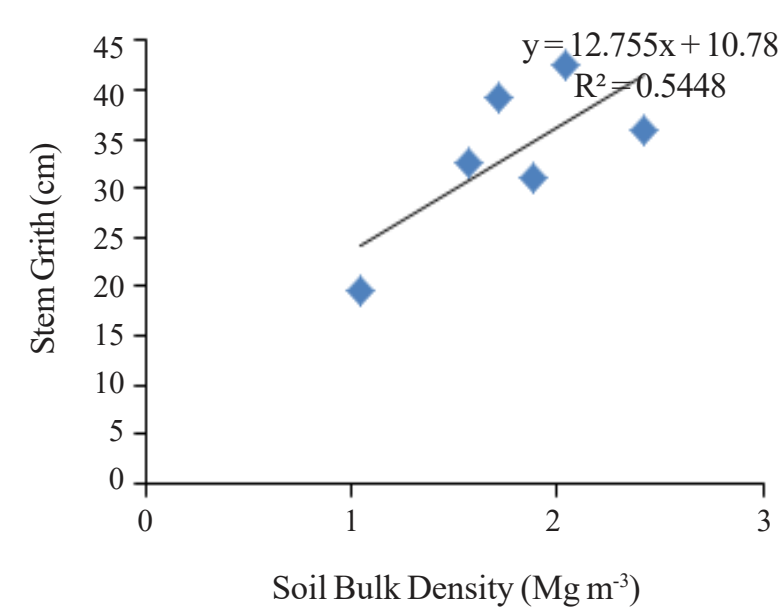

Figure 5. Relationship between force of harvesting and soil bulk density under soil compaction. L Linear (energy).

The regression analysis between bulk density and force (Figure 5) and energy (Figure 6) in harvesting groundnut showed a positive relationship with low $\mathrm{R}^{2}$ values for force $(0.54)$ and energy (0.42). A positive relationship existed between soil bulk density and soil loss with an $\mathrm{R}^{2}$ value of 0.88 (Figure 7).

\section{CONCLUSIONS}

The induced soil compaction reduced the growth and the pod yield of groundnut. Compression of the soil beyond bulk density of $1.88 \mathrm{Mg} \mathrm{m}^{-3}$ affected the height, the number of leaves, the

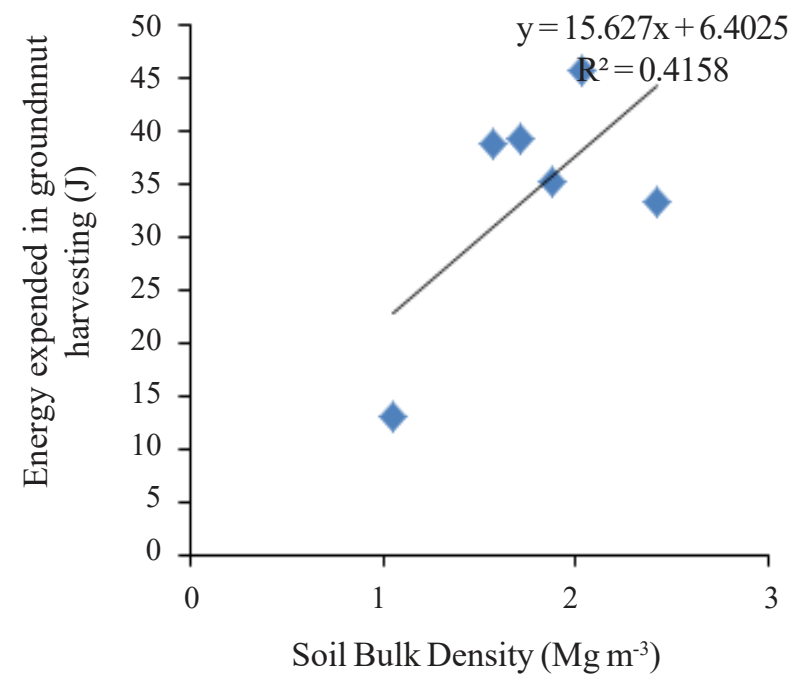

Figure 6. Relationship between force of harvesting and soil bulk density under soil compaction. L Linear (energy).

number of branches, the stem girth, the number of pods, and the roots of groundnut plants. This could have reduced the soil water and air availability as well as restricted the crop roots access to reserves the soil nutrients. A higher soil bulk density borne through soil compaction also reduced the root penetration distance denoting that root penetration becomes more difficult. The force and energy expended in harvesting the plants increased with increasing soil compaction which indicated that greater force and energy will be needed to harvest crops from compacted soil. The farmers should be discouraged from using heavy implements in tillage practices that can cause soil compaction to reduce

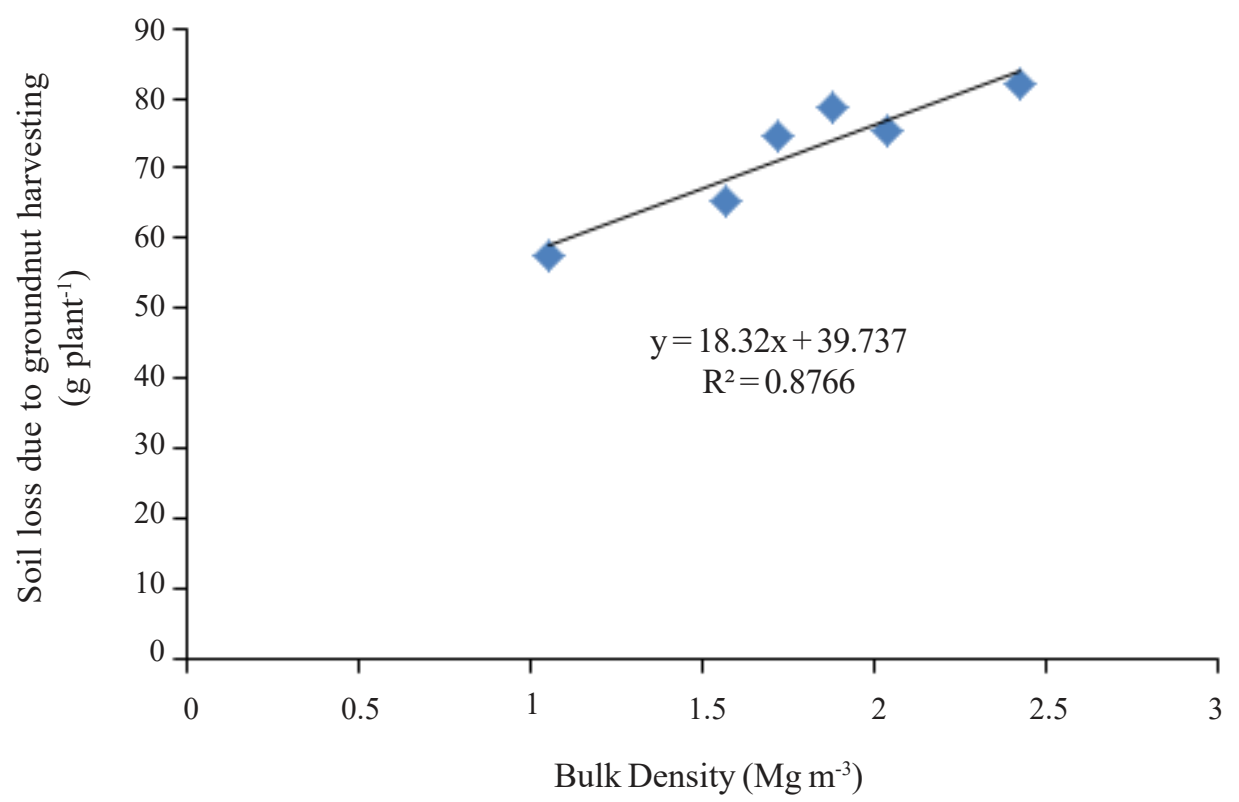

Figure 7. Relationship between force of harvesting and soil bulk density under soil compaction. —— Linear (energy). 
the cost of harvesting crops in compacted soils and more importantly reduced soil loss due to adherence to the roots during crop harvesting.

\section{REFERENCES}

Abdulai A and W E Huffman. 2005. The diffusion of new agricultural technologies: The case of crossbred-cow technology in Tanzania. Am J Agr Econ 87: 645-659.

Aiyelari EA, SO Oshunsanya, JA Fagbenro, FO Oritsejafor and EA Ewetola. 2013. Groundnut (Arachis hypogeal L.) growth and yield as affected by soil compaction. Environtropica 9 \& 10: 73-83.

Babalola O, SO Oshunsanya and K Are. 2007. Effect of vetiver grass (Vetiveria nigritana) strips, vetiver grass mulch and organomineral fertilizer on runoff; soil losses, and maize (Zea mays) yield. Soil Till Res 196: 6-18.

Babalola O. 2007. Soil Erosion Problems in Nigeria: The use of vetiver system technology. University of Ibadan, Ibadan, Nigeria, 91p.

Bohringer $\mathrm{C}$ and A Loschel. 2006. Computable general equilibrium models for sustainability impact assessment: Status quo and prospects. Ecol Econ 60: 49-64.

Bray RH and IT Kurtz. 1945. Determination of total and available forms of phosphorus in soils. Soil Sci: 59: 45-49.

Bremner JN and CS Mulvary. 1965. Total nitrogen. In: Sparks (ed.). Methods of Soil Analysis, American Society of Agronomy, pp. 599-622.

Cavatassi R, L Lipper and U Narloch. 2011. Modern variety adoption and risk management in droughtprone areas: insights from the sorghum farmers of eastern Ethiopia. Agr Econ 42: 279-292.

Chen YL, J Palta, J Clements, B Buirchell, KH Siddique and Z Rengel. 2014. Root architecture alteration of narrow-leafed lupin and wheat in response to soil compaction. Field Crops Res 165: 61-70.

Chude VO, SO Olayiwola, AO Osho and CK Daudu. 2011. Fertilizer use and management practices for crops in Nigeria. Fourth edition. Federal Fertilizer Department, Federal Ministry of Agriculture and Rural Development, Abuja, Nigeria, pp 1-59.

Dada POO, OR Adeyanju and OJ Adeosun. 2016. Effects of soil physical properties on soil due to manual yam harvesting under a sandy loam environment. Int Soil Water Conserv Res 4: 121- 125.

Esu IE. 1991. Detailed soil survey of NIHORT Farm at Bunkure, Kano State, Nigeria. Institute for Agricultural Research, Ahmadu Bello University, Zaria, Nigeria, $72 \mathrm{pp}$.

Etana A, M Larsbo, T Keller, J Arvidsson, P Schjonning, J Forkman and N Jarvis. 2013. Persistent subsoil compaction and its effects on preferential flow patterns in a loamy till soil. Geoderma 192: 430436.
Ewetola EA. 2017. Quantifying tillage and vetiver grass (Vetiveria nigritana Stapf) strips spacing effects on runoff, soil loss, and maize yield in southern guinea savanna of Nigeria. J Northeast Agr Univ 24: 1-18.

FAO [Food and Agriculture Organization]. 2011. The State of the World's Land and Water Resources for Food and Agriculture. Food and Agriculture Organization of the United Nations: Rome, Italy; Earthscan: London, UK, 2011.

Gee GW and DOr. 2002. Particle size analysis. In: Dane and Topp (Eds.) Methods of Soil Analysis, Methods of Soil Analysis. Am Soc Agron pp. 255-293.

Isabirye M, G Ruysschaert, L Vasn linden, J Poesen, M K Magunda and J Deckers. 2006. Soil losses due to cassava and sweet potato harvesting: A case study from low input traditional agriculture. Soil Till Res 92: 96-103.

Keller T, M Lamande, S Peth, M Berli, JY Delenne, W Baumgarten and D Or. 2013. An interdisciplinary approach towards improved understanding of soil deformation during compaction. Soil Till Res 128: 61-80

Lindemans I 2002. Milieu-economischeaspecten van tarragrond. Unpublished MSc. Thesis, Department of Geography, K.U. Leuven.

Nelson DW and LE Sommers. 1996. Total carbon, organic carbon, and organic matter. In: Sparks (eds). Methods of Soil Analysis. American Society of Agronomy, pp. 961-1010.

Nunes MR, JE Denardin, EA Pauletto, A Faganello and FS Pinto. 2015. Effect of soil chiseling on soil structure and root growth for a clayey soil under no-tillage. Geoderma 259 (-260): 149-155.

Obafemi OO and AY Mouiz. 2019. Effect of soil compaction on the growth and nutrient uptake of Zea mays $\mathrm{L}$. Sustain Agr Res 8: 46-54.

Oku EE, Aiyelari EA and KO Asubonteng. 2015. Using vetiver technology to control erosion a $n$ d improve productivity in slope farming. In: United Nations University Institute for Natural Resources In Africa (UNU-INRA) Accra, Ghana. 44 pp.

Oshunsanya SO, K Are and O Babalola. 2010. Soil sediment accumulation and crop yields as affected by vetiver buffer strip spacing in southwest Nigeria. In: SO Ojeniyi (ed). Proceedings of the 33rd Annual Conference of the Soil Science Society of Nigeria. Ibadan, Nigeria: Institute of Agricultural Research and Training, Ibadan. pp. 50-58.

Oshunsanya SO. 2016. Quantification of soil loss due to white cocoyam (Colocasia esculentus) and red cocoyam (Xanthosoma sagittifolium) harvesting in traditional farming systems. Catena 137: 134-143.

Oshunsanya S O, Y Hanqing, and L Yong. 2018. Soil loss due to root crop harvesting increases with tillage operations. Soil Till Res 181: 93-101.

Poesen JW, G Verstraeten, R Soenens and L Seynaeve, 2001. Soil losses due to harvesting of chicory roots and sugar beet: an underrated geomorphic process? Catena 43: 35-47. 
Poesen J. 2018. Soil erosion in the Anthropocene: research needs. Earth Surface Process. Landform 43: 64-84.

Rickson RJ. 2014. Can control of soil erosion mitigate water pollution by sediments? Sci Total Environ 468-469: 1187-1197.

Rigo L. 2002. Results of the CIBE survey on topping, dirt tare, and inter professional agreements in European countries. Zuckerindustrie 127: 31-44.

Ruysschaert G, J Poesen, G Verstraeten and G Govers. 2006. Soil losses due to mechanized potato harvesting. Soil Till Res 86: 52-72.
Salem HM, C Valero, MA Munoz, MG Rodriguez and LL Silva. 2015. Short-term effects offour tillage practices on soil physical properties, soil water potential, and maize yield. Geoderma 237: 60-70.

SAS Institute. 2002. SAS/STAT User's Guide. In: Version 8.2. SAS Institute Cary, NC.

Wilson JP and MS Lorang. 2000. Spatial models of soil erosion and GIS. In: AS Fotheringham and M Wegener (eds). Spatial models and GIS: new potential and new models, PA Philadelphia, pp 83108. 